\title{
Integration, functional differentiation and problem-solving in multilevel governance
}

\author{
Philipp Trein $^{1,2}$ (1) | Eva Thomann ${ }^{3}$ | Martino Maggetti ${ }^{1}$
}

\author{
${ }^{1}$ Institute for Political, Historical and \\ International Studies (IEPHI), Faculty of Social \\ and Political Science, University of Lausanne, \\ Switzerland \\ ${ }^{2}$ Institute of European Studies (IES), \\ University of California, Berkeley, USA \\ ${ }^{3}$ Department of Politics, College of Social \\ Sciences and International Studies, University \\ of Exeter, UK

\section{Correspondence} \\ Philipp Trein, Institute for Political, Historical \\ and International Studies (IEPHI), Faculty of \\ Social and Political Science, University of \\ Lausanne, Quartier UNIL-Mouline, Géopolis \\ 4346, Lausanne 1015, Switzerland. \\ Email: josefphilipp.trein@unil.ch

\section{Funding information} \\ Schweizerischer Nationalfonds zur Förderung \\ der Wissenschaftlichen Forschung, Grant/ \\ Award Number: 162832; Université de \\ Lausanne
}

\begin{abstract}
The European Union (EU) is currently facing unprecedented challenges to its problem-solving capacity, such as those represented by pressing transnational crises and by bottomup criticisms towards the European integration process. Moreover, the EU is said to compensate its weak input legitimacy with an enhanced problem-solving capacity. However, the notion of problem-solving itself has remained remarkably vague in the multilevel governance (MLG) literature. This symposium analyses problem-solving in different MLG settings. In this introduction, we identify procedural and operational notions of problem-solving in MLG, and present a structural framework to guide the comparative analyses of multilevel systems along the dimensions of political integration, functional differentiation and decentralization. The contributions to the symposium illustrate how structural elements of different multilevel systems shape both the policy-making process and the politics of problem-solving within these systems. In doing so, they pave the way for further comparative research.
\end{abstract}

\section{1 | INTRODUCTION AND RATIONALE FOR THE SYMPOSIUM}

The question of how multilevel governance is related to problem-solving has been on the research agenda of political scientists for some time. In the 1990s, scholars used the expression 'problem-solving' to denote a mode of policymaking in the EU which aimed at producing coordinated policy outputs to solve shared problems, such as environmental pollution. This mode was opposed to bargaining, where participating actors pursue above all their special interests (e.g., Scharpf 1997, 1999; Benz 2000). In the wake of the euro crisis and its aftermath, problem-solving reappeared more prominently on the public policy and political science research agendas (e.g., Lodge and Wegrich 2014c; Falkner 2016; Braun et al. 2017). However, until today, there is neither a unified understanding of problem- 
solving nor an agreement on how the structural characteristics of multilevel governance systems affect problem-solving. The legitimacy crisis of the European Union, the Brexit process, as well as the current challenges to multilateral international institutions put existing multilevel governance structures under stress. Against this backdrop, it is important to reappraise the problem-solving capacity of multilevel governance. This symposium contributes to filling this research gap, with special attention to the EU, but including multilevel settings beyond the EU.

The selected articles address the relationship between integration, functional differentiation, and problemsolving in multilevel governance settings. Specifically, the four contributions discuss how the presence of multiple and/or intersecting jurisdictions-for example related to the European Union (EU), its member states, regions, and municipalities-affects the governance of pressing policy challenges. The authors also examine how this structural variety in problem-solving processes is linked to democratic policy-making. The articles in this symposium start from the EU as the prototypical case of multilevel governance and then embark on a comparative analysis of different articulations of the relationship between multilevelness and problem-solving in other contexts. The settings analysed in this symposium vary in terms of the functional differentiation of the respective multilevel governance system (Maggetti and Choer Moraes 2018; Tosun and Hartung 2018), such as federal states (Heidbreder et al. 2019) and international organizations (IO) (Ege 2019). This comparative approach allows for a wide-ranging investigation into the challenges of problem-solving in multilevel governance settings. In addition, the articles in this symposium make a conceptual and theoretical contribution to the analysis of multilevel governance: they connect the structural features of multilevel settings to different types of problem-solving processes. Therefore, this symposium contributes to the development of multilevel governance towards a more general theory of policy processes (Tortola 2017), which also goes beyond the European Union.

In what follows, we first introduce the notions of problem-solving adopted in this symposium. We then hone in on three structural dimensions of multilevel governance relevant for problem-solving: political integration, functional differentiation and decentralization. Afterwards, we introduce the various contributions of the symposium, and discuss how they illustrate the interplay of integration, functional differentiation and problem-solving in multilevel governance.

\section{DEFINING PROBLEM-SOLVING}

For the purposes of this symposium, we follow the definition of problem-solving that Maggetti and Trein (2019) put forward in their article on the dynamics of multilevel governance systems: According to this definition, policy-makers in charge of formulating, drafting, adopting, implementing, and evaluating policies,

(a) Make policies in the sense of 'puzzling' (on society's behalf) as opposed to 'powering' (Heclo 1974); so as to (b) deal with problems that are perceived important for society by organized groups and/or by policy-makers themselves (Cohen et al. 1972); through (c) the cooperative production of a policy output that is expected to be collectively beneficial in making a contribution to solve the policy problem at stake (Elgström and Jönsson 2000).

The term puzzling was coined by Hugh Heclo in his seminal work on social politics in Britain and Sweden. Therein, the author argues that,

Policymaking, is a form of collective puzzlement on society's behalf; it entails both deciding and knowing. The process of making pension, unemployment, and superannuation policies has extended beyond deciding what 'wants' to accommodate, to include problems of knowing who might want something, what is wanted, what should be wanted, and how to turn even the most sweet-tempered general agreement into concrete collective action. (Heclo 1974, p. 305) 
Heclo uses the term 'puzzling' to point out that policy-makers' actions are also driven by the urge to solve policy problems and not only by prevalent political constellations. In other words, puzzling entails political action intended to solve policy problems such as climate change or unemployment. As we show in another article (Thomann et al. 2019), this definition entails both procedural notions of problem-solving and the outcomes of such processes.

\section{1 | Problem-solving as a process}

A procedural perspective on problem-solving was introduced into EU studies during the 1990s to convey the idea that EU member states need to cooperate with one another to successfully deal with policy challenges. This need for cooperation arises because the increasing integration of the EU limits the capacity of member states to make policies on their own. The problem is that-in some policy domains-member states cannot produce effective policies, such as product regulations, at the national level, but they need to cooperate internationally (Scharpf 1997). Federal states face a similar situation although they have much more integrated actors and political institutions, such as a strong national parliament and party system, which the EU is lacking (Fossum and Jachtenfuchs 2017). In these contexts, intergovernmental negotiations are important but they are subject to the logic of party competition in parliamentary democracy, especially in a situation where policy-makers are confronted with redistribution in a zero-sum game. Consequently,

... external pressure induces changes, but it also shifts negotiations from problem-solving among experts to 'distributive bargaining' among leaders of governments influenced by party competition. Policy-making results, at best, in a compromise. (Benz 2000, p. 26)

This specific procedural perspective understands problem-solving as a pattern of behaviour that prioritizes solving collective policy problems over preferences related to constituencies' or specific groups' particular interests. Problem-solving is especially important for multilevel governance systems lacking direct democratic legitimacy such as the EU because their legitimacy derives precisely from their capacity to solve these collective problems (Scharpf 1999, 2003). Thus, problem-solving entails policy solutions that substantially include concerns of the parties affected by the problem (Sager 2005, p. 237). The absence of problem-solving entails behaviour that aims to protect particular interests even at the expense of other groups or constituencies involved in the policy process. In different terms, problem-solving means that decision-makers are willing to forego the interests of their constituency for the sake of an effective collective policy solution, if the two are not aligned (Trein 2018).

In harking back to the work of Kingdon (Kingdon 1995), on the one hand, and the contributions by Benz (2013) and Scharpf (1992), on the other, Braun et al. (2017) adopt a broader perspective on problem-solving. They distinguish a problem-solving stream and a power stream to analyse the policy-making dynamics of consolidation policies in federal states. According to these authors,

The problem-solving stream integrates both the definition of problems and their agenda setting as well as the search for solutions (something Kingdon distinguished from each other). ... The power stream has its own developmental logic, but it can be triggered by events in the problem-solving stream. If actors' interests are touched upon, the federal power stream is there to deal with this situation and to find a solution in order to avoid institutional instability.

The authors conceive both streams as systems that seek to maintain the institutional stability of the political system-either by solving a policy problem or by 'mediating interests between federal actors' (Braun et al. 2017, p. 34). In this sense, problem-solving is a logic of action in policy-making that aims to deal with a policy problem, such as climate change, unemployment, or excessive public debt, to preserve political stability. 
As Thomann et al. (2019) highlight, the procedural understanding of problem-solving includes other elements that are important to problem formulation, agenda-setting, policy-making, implementation, and evaluation. For example, problem-solving is related to learning, notably to learning intended to solve a policy problem (Dunlop et al. 2018). Whereas political learning occurs when policy-makers strive to improve their political strategies (Trein 2018 , p. 260), learning as problem-solving focuses on learning as a means to deal with policy challenges, for example by updating knowledge about policy instruments with the intention to create more effective policies (Vagionaki and Trein 2019). Other procedural forms of problem-solving include, for instance, problem (re)definition and problem management (see Thomann et al. 2019).

So far, scholars have used this procedural perspective to examine the problem-solving capacity of supranational and intergovernmental settings, namely in the context of European studies and research on federal states. There is room for more research that explores to what extent and under which structural conditions policy-making contributes to solving political problems, as opposed to engaging in symbolic reforms or in 'powering'. In this way, studying problem-solving as a process also points our attention to different-procedural, programmatic and politicalconceptions of policy success which also include notions of democratic accountability and legitimacy (Marsh and McConnell 2010; Thomann 2019).

\section{2 | Problem-solving as an outcome}

The definition of problem-solving mentioned above incorporates expectations about the outputs and outcomes of policy processes but does not engage with them directly. Another, more operational, perspective on problem-solving relates more directly to policy implementation and evaluation and refers to the actual outputs and broader outcomes of the process. The question driving these perspectives is whether policy problems have actually been solved. Recent scholarship has returned to the notion of problem-solving to ask if the modern state is still effective in dealing with pressing policy challenges, such as climate change, ageing populations and public debt. Therein, scholars refer to the expression 'problem-solving device' (Lodge and Wegrich 2014b, p. 5) to assess whether administrative capacities and policy instruments of the nation state still suffice to solve the policy challenges mentioned (Lodge and Wegrich 2014b, 2014c). The authors conclude that despite the increasing importance of markets and networks (Lodge and Wegrich 2014a, pp. 290-91) the state remains crucial to provide solutions to policy problems (Lodge and Wegrich 2014a, p. 276):

... considering administrative capacities as one key element to contribute to the problem-solving capacity of the contemporary state reflects a view of problem-solving that accepts limitations and boundaries, and therefore demands critical reflection rather than enthusiastic endorsement of reform templates. (Lodge and Wegrich 2014a, 290-91)

In another contribution, Thomann and Sager argue that scholars need to look at policy implementation and consider that multilevel systems deliberately produce different approaches to problem-solving. In referring to the work on policy implementation in federal states, they argue that different problem-solving strategies are 'actually an intended result of decentralized implementation structures' (Thomann and Sager 2017, p. 1255). Depending on the circumstances, transnational regulations can actually be more effective if they are adapted, that is, 'customized' to local contexts during implementation (Thomann 2019). Thus, while compliance with policies can be one operational criterion for problem-solving, it also implies looking at patterns of performance (Bondarouk and Mastenbroek 2018), customization (Thomann 2015, 2019) and effectiveness (Peters et al. 2018).

This perspective, too, implies a closer look at what success means for a policy (Marsh and McConnell 2010). For example, decentralized implementation can also allow for blame avoidance or blame shifting (e.g., Mortensen 2013), especially where contested policies are concerned (e.g., Tosun et al. 2019). In summary, while a procedural understanding of problem-solving emphasizes integration beyond the nation state, thinking of problem-solving as an 
outcome suggests that there is a crucial role for differentiation, too. The important, empirical criterion under an operational perspective is whether and how policy problems have been tackled against specific criteria of problemsolving outcomes.

However, the research on operational problem-solving in multilevel governance has mostly focused on legal compliance with EU law (Treib 2014); beyond that, this analytic perspective is in its beginnings in the field of multilevel governance research (see Zhelyazkova et al. 2016; Thomann and Sager 2017; Thomann 2019). There is room for contributions that further develop the notion of operational problem-solving. One possible avenue for such an undertaking would be to examine the connection between implementation failures and problem-solving, for example by exploring the types of implementation failure or success (Jordan 1999), and drawing on concepts from the policy evaluation literature (Mastenbroek et al. 2016; Dunlop and Radaelli 2019).

Both procedural and operational modes of problem-solving have a special relevance in multilevel governance, as we discuss in the next section.

\section{3 | MULTILEVEL GOVERNANCE AND PROBLEM-SOLVING IN AND BEYOND THE EU}

Many policy challenges that confront policy-makers today-particularly in times of crisis and turbulence, such as for climate policy and for the Brexit process-require coordination beyond the national government, for example with subnational, international, and private actors (Ansell et al. 2017, pp. 2-3). Hierarchical forms of coordination have reached their limits (Schout and Jordan 2005), whereas non-hierarchical coordination and functional policy solutions have gained in importance (Hooghe and Marks 2003). Therefore, multilevel governance arrangements become ever more prominent (Hooghe and Marks 2001). The multilevel nature of these arrangements means that political structures are intertwined in a way that implies the need for state and non-state actors from different levels-nation state, regional, local, and international-to negotiate to find common policy solutions (Bache et al. 2014) or learn from one another (Kohler-Koch and Rittberger 2006; Dunlop et al. 2018) to deal with pressing policy challenges.

Multilevel governance has sparked a lot of interest across different areas of research in political science and public policy. A recently published compendium of essential readings in multilevel governance shows that the EU and its member states (and regions) are the main 'playing field' for concept development and empirical application of multilevel governance (Bache and Flinders 2015). Accordingly, this line of research is now the driver for theory-building in the multilevel governance literature (Stephenson 2013). At the same time, the question whether the EU resembles more a traditional international organization or a (federal) state remains open. As Cini and Pérez-Solórzano (2016, p. 3) highlight,

... although it might seem fair to claim that the European Union is unique, or a hybrid body, even this point can be contentious where it prevents researchers from comparing the EU to national systems of government and international organizations.

Some strands of EU research have approached the EU as a unique and unprecedented administrative, political and economic system sui generis that requires a distinctive analytical approach (Kohler-Koch and Eising 1999; Woll 2006). Conversely, it has been repeatedly argued that research on the EU could undertake more efforts to connect their insights to the broader study of similar or analogous phenomena (e.g., Börzel and Hosli 2003; Trondal 2010; Treib 2014; Thomann and Sager 2017). The current symposium embraces this second position.

The fragmentation of the EU literature arguably complicates theory-building about multilevel governance in general. Indeed, the theoretical status of multilevel governance has remained ambiguous. On the one hand, there is widespread agreement about the descriptive prescriptions-the distinction between different levels and the empirical focus of the contributions (Enderlein et al. 2010; Bache and Flinders 2015). On the other hand, we still lack precise hypotheses about causal mechanisms in multilevel governance systems. This theoretical ambiguity has allowed 
researchers to apply multilevel governance to a variety of empirical contexts, yet the inferential power of the concept has remained weak (Piattoni 2010; Tortola 2017).

An important dimension of procedural problem-solving in multilevel governance concerns the democratic legitimacy and accountability of these systems. The presence of a multitude of levels tends to strengthen governments over parliaments as the former can more easily play two-level games. For example, in the Council of the EU, governments of member states are expected to cooperate to find common policies to deal with EU-wide problems. However, national governments derive their legitimacy to act on this through their national parliaments. This indirect form of representation results in weak input legitimacy for EU policies because the European parliament and party system did not superimpose a European political system on EU member states. Scholars have argued that this lack of input legitimacy is not a problem because the traditionally strong intergovernmental consensus of the EU is enough to legitimize EU decisions (Scharpf 2003). Moreover, it is argued that the EU compensates for weak input legitimacy with superior output legitimacy. That is, the EU is argued to have an increased capacity to address complex and cross-boundary policy problems and ultimately improve the well-being of its citizens (Schmidt 2013). Thus, the EU's problem-solving capacity is a crucial source of political legitimacy. However, this assertion-that is, the extent to which the EU does indeed have a superior output legitimacy-is seldom subjected to empirical scrutiny.

Despite its weak input legitimacy, the EU's system of governance comes along with different forms of accountability, such as peer-accountability in policy networks, for example in the Open Method of Coordination, which differ from accountability in representative democracy where politicians are accountable to voters more directly (Papadopoulos 2010). This peculiar form of accountability went along with a problem-solving-oriented style of policy-making at the European level until European integration became a politicized issue itself (Down and Wilson 2008; Hix 2008; Hooghe and Marks 2009; De Vries 2018). In the wake of the euro crisis, the EU policy-making style resulted in strategic bargaining amongst euro countries. Procedural problem-solving focused on avoiding the collapse of the eurozone, but dealing with the social consequence of the crisis (that is, operational problem-solving) remained the problem of the member states (Schelkle 2017; Papadopoulos and Piattoni 2019).

In summary, the EU is facing a crisis that not only puts into question the overall process of European integration, but also challenges the EU's capacity to effectively solve collective problems by making the most of its multilevel governance arrangements. This makes it a timely case for exploring the question of the problem-solving capacity of multilevel governance from a broader perspective that also includes other political systems (Tosun et al. 2014; Falkner 2016; Kamkhaji and Radaelli 2017; Rittberger and Blauberger 2018). The symposium explores this capacity with a dynamic perspective, offering lessons for the EU and beyond. The unravelling of sovereignty and the challenges to democratic legitimacy and accountability render redistribution and horizontal coordination at the national level even more complicated in multilevel systems (Scharpf 1997; Papadopoulos 2010; Egeberg and Trondal 2016). What can we learn from the comparison of different policy sectors for the problem-solving capacity of multilevel settings? How can different theoretical and empirical approaches produce cumulative knowledge about integration, functional differentiation and problem-solving in multilevel settings? Accordingly, the contributions engage in theory-building on multilevel governance by comparing the EU and other cases (Ege 2019; Heidbreder et al. 2019; Tosun et al. 2019), different policy sectors (Ege 2019), or by combining new and innovative theoretical perspectives (Maggetti and Trein 2019). Thereby, the symposium aims, on the one hand, to advance our current understanding of policy-making in the EU, and, on the other, to improve our cumulative knowledge of the potential and limits of the problem-solving capacity of multilevel governance arrangements.

\section{4 | STRUCTURAL CONDITIONS FOR PROBLEM-SOLVING IN DIFFERENT MULTILEVEL SETTINGS}

Analytically, this symposium starts by linking different institutional settings to procedural aspects of problem-solving. In the following, we argue that these institutional settings are characterized by three structural dimensions that are 
relevant for problem-solving in multilevel governance: political integration, functional differentiation and decentralization. The configurations resulting from their combination determine the specific institutional framework that forms the context in which a policy problem can be governed. In the following, we discuss these three structural dimensions-political integration, functional differentiation and decentralization-and outline their implications for problem-solving.

The first structural dimension that is important for problem-solving in multilevel settings is political integration. We define political integration from the perspective of the polity, for example, concerning the integration of general-purpose political institutions (Hooghe and Marks 2003). For example, in federal states, the 'right to decide' has somewhat disintegrated because territorial governments often have considerable legislative autonomy, which is institutionalized in subnational parliaments (Braun 2000; Biela et al. 2012). The same is true for the devolved governments of the UK. At the source of the EU literature, political integration refers to the process where actors from various levels, for example member states, shift their loyalties, political activities, and expectations toward a new centre which results in a new political community that is superimposed on existing states (Haas 1958). For the purposes of our framework, we understand political integration as the degree to which decision-making is institutionalized at the centre of the multilevel polity. In other words, a high degree of political integration indicates the concentration of decision-making power. Political integration can coevolve with policy integration across levels of government (Tosun and Lang 2017; Trein 2017; Trein et al. 2019). For example, in the EU, the integration of political competencies alternated with the transfer of policy-specific competencies to the higher level of government.

The second structural dimension that is relevant for problem-solving is functional differentiation. Functional differentiation is a term that originates in sociological theory where it has been used to explicitly and implicitly analyse the development of independent subsystems in modern society, such as the legal system or the education system (Albert et al. 2013). We use the concept to denote the process of functional policy specialization characterizing a specific multilevel system. Accordingly, the EU, which is the starting point for our theoretical reflections, should not be considered through the prism of political integration, as was the case in the early literature on European integration. Instead of evolving towards a new nation state, the EU went through a process of differentiated integration. In other words, political authority moved to the upper level in task-specific jurisdictions (Hooghe and Marks 2003, pp. 237-39). Policy-makers delegated authority to the EU in some policy areas, such as banking and environmental protection, but not in other policy fields, such as social policy (Leuffen et al. 2012). Scholars coined the term differentiated integration, referring to the fact that the EU's centralization (vertical integration) and territorial shape (horizontal integration) vary across policies (Schimmelfennig et al. 2015). In particular, core state powers such as taxation have only moved marginally to the European level and remain largely locked in at the national level. Legally speaking, the EU remains a supranational organization rather than a state (Genschel and Jachtenfuchs 2018). Thus, we refer to functional differentiation as the mere integration of policy-relevant competencies across levels of government (Tosun and Lang 2017; Trein et al. 2019) but not the political integration that refers to core state powers. In this case there is policy integration but no, or only limited, political integration.

The third structural dimension is decentralization. We distinguish it from integration and functional differentiation because it relates to what scholars of federalism have labelled the 'right to act' (Braun 2000; Biela et al. 2012). This implies that lower levels of government do not have the freedom to make their own laws in a given policy area but they are responsible for implementation, they enjoy freedom to implement policy in a way that fits their particular needs, and they can collect the necessary resources from their constituencies. Even in countries with a strong national government, such as the UK, local governments have some discretion in implementing national policy according to how they see that it fits with their needs and collect taxes.

We combine these three dimensions into an analytical space that allows us to analyse the institutional configurations that are pertinent for problem-solving in multilevel systems. The three structural dimensions-political integration, functional differentiation and decentralization-permit us to compare different types of multilevel systems, for example unitary states, federal states, the EU, and international organizations (Figure 1). The political integration axis spans from 'no integration' to full integration of political competencies in the multilevel polity. In other words, this 


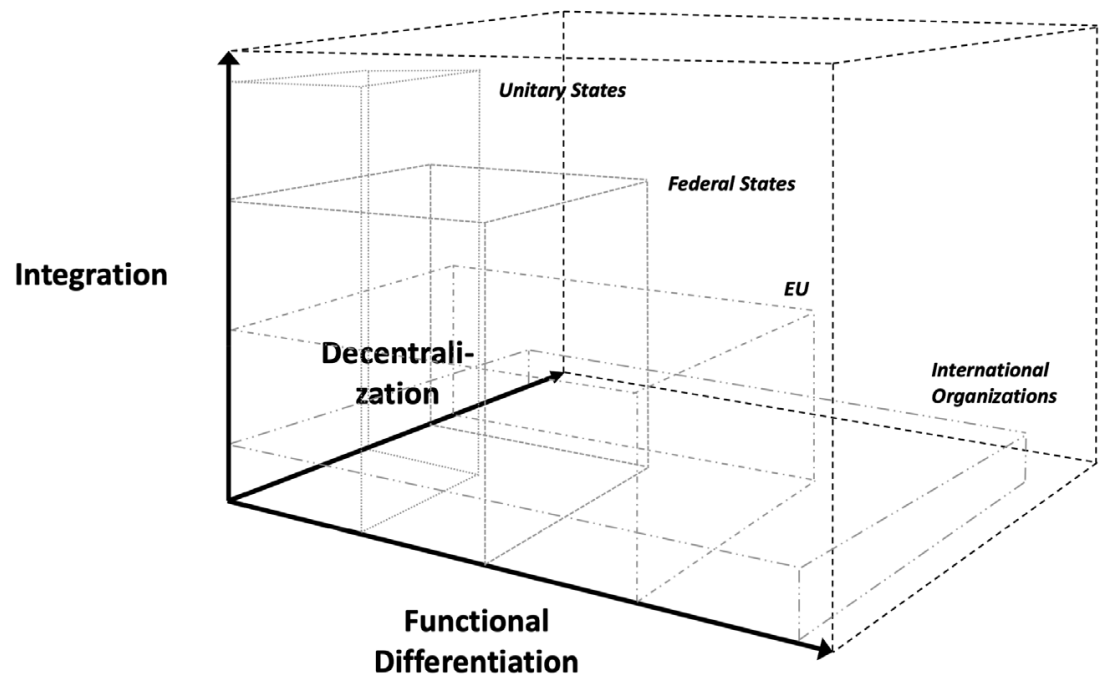

FIGURE 1 Structural dimensions of multilevel governance and problem-solving

axis covers the variation from a fully integrated 'simple polity', such as in unitary states, to a 'compound polity' (Schmidt 2006, p. 229), which is, in our case, international organizations. Federal states and the EU represent intermediary cases, with federal states representing a more institutionalized multi-tiered political system, and the EU being closer to the other pole indicating incomplete central political and ongoing policy integration of the constituent units. The functional differentiation axis coevolves with the former and spans from 'limited functional differentiation' to 'significant functional differentiation'. In harking back to the literature on differential European integration, this dimension emphasizes the integration of task-specific policy competencies across levels of government (Leuffen et al. 2012; Schimmelfennig et al. 2015). The third dimension spans from 'no decentralization', that is, no 'right to act' for lower-level units, to a strong 'right to act' that includes a lot of freedom, for example concerning policy implementation for lower-level jurisdictions (Biela et al. 2012).

These configurations serve as a heuristic for the empirical analysis of specific cases or groups of multilevel systems. On the one hand, the EU is a 'real-type' of an existing multilevel system. On the other, unitary states, federal states, and international organizations may have some features of multilevel systems that vary in their real manifestations. For example, the United Nations is less differentiated functionally than the World Meteorological Organization, which covers only one particular policy field.

In the multilevel governance literature, private actors also range in the structures and the processes of multilevel governance as channels of sideways reallocation of authority away from the central state (Hooghe and Marks 2003; Zürn et al. 2010). However, we focus on different levels of government because we do not consider private actors as configuring a structural dimension per se. In theory, they can be part of the model by including them in any level of government. This complexification is nevertheless beyond the scope of the present article.

\section{5 | CONTRIBUTIONS TO THE SYMPOSIUM}

This analytical space is the starting point for the four contributions to this symposium, which deepen the theoretical discussion on problem-solving in multilevel systems and illustrate how the structural dimensions of political integration, functional differentiation and decentralization relate to procedural problem-solving (see Table 1).

The contribution by Maggetti and Trein covers the space of Figure 1 downwards from federal states, and presents a theoretical framework of the conditions under which a specific multilevel governance arrangement 
TABLE 1 Summary of contributions

\begin{tabular}{|c|c|c|c|c|}
\hline Contribution & Research question & $\begin{array}{l}\text { Notion of } \\
\text { problem-solving }\end{array}$ & $\begin{array}{l}\text { Relation to analytical } \\
\text { framework and } \\
\text { empirical focus }\end{array}$ & Main findings \\
\hline $\begin{array}{l}\text { Maggetti } \\
\text { and Trein }\end{array}$ & $\begin{array}{l}\text { Under what conditions } \\
\text { do specific multilevel } \\
\text { governance } \\
\text { arrangements } \\
\text { contribute to } \\
\text { problem-solving or, } \\
\text { conversely, to the } \\
\text { creation of new } \\
\text { problems? }\end{array}$ & Procedural & $\begin{array}{l}\text { Variance in: } \\
\text { political integration, } \\
\text { functional } \\
\text { differentiation, and } \\
\text { decentralization } \\
\text { Comparison of the EU } \\
\text { and federal states }\end{array}$ & $\begin{array}{l}\text { MLG both solves and } \\
\text { creates problems } \\
\text { Problem-solving and } \\
\text { problem creation can } \\
\text { reconfigure MLG } \\
\text { structures } \\
\text { Typology of mechanisms }\end{array}$ \\
\hline $\begin{array}{l}\text { Heidbreder } \\
\text { et al. }\end{array}$ & $\begin{array}{l}\text { How can } \\
\text { direct-democratic } \\
\text { referendums unfold a } \\
\text { legitimacy-enhancing } \\
\text { and problem-solving } \\
\text { function? }\end{array}$ & $\begin{array}{l}\text { Procedural } \\
\text { Legitimacy of } \\
\text { referendums }\end{array}$ & $\begin{array}{l}\text { Politically integrated } \\
\text { vs. functionally } \\
\text { differentiated } \\
\text { Comparison of the EU } \\
\text { and Switzerland }\end{array}$ & $\begin{array}{l}\text { Scope conditions under } \\
\text { which referendums are } \\
\text { conducive or hindering } \\
\text { for problem-solving and } \\
\text { legitimacy } \\
\text { Levels of integration affect } \\
\text { legitimacy of } \\
\text { referendums } \\
\text { Informal practices (not only } \\
\text { structures) contribute to } \\
\text { procedural } \\
\text { problem-solving }\end{array}$ \\
\hline Ege & $\begin{array}{l}\text { What are the varieties } \\
\text { of management } \\
\text { change in } \\
\text { international public } \\
\text { administrations } \\
\text { (IPAs)? }\end{array}$ & $\begin{array}{l}\text { Procedural } \\
\text { International } \\
\text { level } \\
\text { Administrative } \\
\text { reforms }\end{array}$ & $\begin{array}{l}\text { Variation in functional } \\
\text { differentiation and } \\
\text { political integration } \\
\text { Comparison of the EU, } \\
\text { the Food and } \\
\text { Agriculture } \\
\text { Organization of the } \\
\text { United Nations, and } \\
\text { the Organization for } \\
\text { Economic } \\
\text { Cooperation and } \\
\text { Development }\end{array}$ & $\begin{array}{l}\text { Typology and } \\
\text { measurement of } \\
\text { management change } \\
\text { Central steering and } \\
\text { administrative } \\
\text { problem-solving have } \\
\text { generally improved in } \\
\text { IPAs over time }\end{array}$ \\
\hline Tosun et al. & $\begin{array}{l}\text { How has the EU } \\
\text { proceeded in } \\
\text { translating the } \\
\text { abstract concept of } \\
\text { Environmental Policy } \\
\text { Integration (EPI) into } \\
\text { concrete policy } \\
\text { tools? }\end{array}$ & $\begin{array}{l}\text { Procedural } \\
\text { Delegation of } \\
\text { competence to } \\
\text { define a policy } \\
\text { concept and } \\
\text { transform it } \\
\text { into a practical } \\
\text { tool }\end{array}$ & $\begin{array}{l}\text { Variation in functional } \\
\text { differentiation and } \\
\text { decentralization } \\
\text { Comparison of the EU } \\
\text { and international } \\
\text { organizations }\end{array}$ & $\begin{array}{l}\text { The EU delegates policy } \\
\text { authority if (a) policy } \\
\text { concepts are mature and } \\
\text { political uncertainty and } \\
\text { oversight costs are not } \\
\text { too high, and (b) the cost } \\
\text { of externalizing policy } \\
\text { knowledge compensates } \\
\text { for costs resulting from } \\
\text { political uncertainty and } \\
\text { control over policy } \\
\text { formulation and } \\
\text { implementation }\end{array}$ \\
\hline
\end{tabular}


contributes to problem-solving or, conversely, to the creation of new problems. They make three innovative contributions to contemporary theories on multilevel governance. First, the authors point our attention to the fact that multilevel governance not only solves problems; crucially, it can also potentially generate new problems. However, the authors point out that currently no coherent framework exists that lays out the conditions under which either of the two is the case. The authors fill this gap by, second, highlighting that the ways in which multilevel governance systems engage in problem-solving or problem-generation feedback with institutional arrangements and can lead to the reconfiguration of these arrangements. Based on these premises, Trein and Maggetti propose six non-exhaustive mechanisms of how these reconfigurations may produce further upward, downward or sideways delegation. This results in a hands-on explanatory typology (Elman 2005) of the varieties of self-reinforcing dynamics that result from the interplay of problem-solving and problem-generation and how they can trigger a change in the type of multilevel governance arrangements (from Type I to Type II or vice versa) and in the direction of delegation (i.e., centrifugal or centripetal).

In a nutshell, Maggetti and Trein argue that a multilevel system that effectively resolves problems without generating many new problems should remain relatively stable in structural terms. Conversely, a system which is ineffective in solving problems and generates new problems should experience substantial structural change. However, there also exist systems that are effective in addressing current problems, but also generate a considerable amount of new problems. While the overall architecture of such systems should remain stable, the authors expect changes in the direction of delegation. Finally, there are multilevel governance systems that, while ineffectively addressing problems, do not tend to generate new problems as well. In these cases, the authors expect an adjustment of the type of governance system but not in the direction of delegation.

Going back to the scheme set out in Figure 1, a central contribution of this framework lies in uncovering how the type of multilevel governance system and the particular combination of functional differentiation and integration can create institutional dynamics. Thus, they argue, the empirical manifestation of these dimensions is not only a result of both problem-solving and problem-generation: it also leads to changes in these structures. Admittedly, this argument involves a certain amount of circularity. Nonetheless, this kind of self-reinforcing dynamics is a reality not only of multilevel systems, but of governance more generally, as historical institutionalist perspectives also highlight (Pierson 2004). The focus of Maggetti and Trein on dynamics and the shift from problem-creation to problem-solving illustrates that such a perspective has the potential to bear important explanatory power for understanding EU governance, as well as other varieties of multilevel governance. Of course, the proof of the pudding is in the eating and their framework now awaits empirical testing and refinement.

The article by Heidbreder et al., in turn, focuses on the question of whether and how direct-democratic referendums can unfold a legitimacy-enhancing and problem-solving function, by adopting a comparative perspective between the EU and a federal state. The crucial puzzle motivating their article is the observation that referendums on EU-related matters in member states are frequently compared to referendums in the Swiss semi-direct democratic system in order to call for more legitimate decision-making processes in the EU. However, so they argue, there are fundamental differences between these two systems regarding the contexts in which referendums operate. This contextual variation, they argue, accounts for important differences in the extent to which referendums can actually contribute to meaningful problem-solving and enhance the legitimacy of the resulting decisions. To this end, they define referendums as instances of procedural problem-solving: as decisions on specific problems, referendums are decided by the people and result in a collective decision via a vote. However, referendums may serve not only to address policy problems, but also the wider problems of legitimacy and politics.

The central argument presented by Heidbreder et al. is that several contextual features of the Swiss and the EU system, respectively, suggest important scope conditions under which referendums are conducive or hindering for problem-solving. At the formal level, the crucial difference lies in the fact that referendums are an institutionalized part of the regular representative system in Switzerland, while this is not the case in the EU: neither are referendums an established policy-making mode at the EU level, nor in most member states. This already weakens the legitimacy of referendums as a problem-solving mode, which is reinforced by the incongruence between the set of actors who 
are allowed to vote and the set of actors who are affected by it at the EU, but not the Swiss, level. Moreover, the authors discuss several formal and informal practices in the respective political systems and how they are designed to complement and embed direct democracy therein to safeguard and prevent unintended effects in the Swiss case, while being prone to producing unintended effects, tensions, and reinforce politicization in the EU case. Based on a comprehensive review of the empirical literatures on EU referendums and Swiss referendums, the authors discuss how the EU literature can learn from Swiss insights on the reasons why referendums are called upon, the factors that account for voting outcomes, and the resulting effects on policies, politics and the polity.

Heidbreder et al. make a strong case that the Swiss system cannot meaningfully be cited when discussing the potential advantages of EU referendums held in single member states. They argue that this is the result of the lack of crucial scope conditions needed in the current EU architecture for making direct democracy work. Relating this argument back to Figure 1, a decisive factor is the level of integration of the multilevel system. Moreover, while often being of limited functional scope, EU referendums almost inevitably affect the entire EU polity. A unique contribution of this article lies in going beyond theoretical or normative arguments on the legitimacy of direct democracy in the EU, by presenting to the reader a digested and nuanced discussion of the empirical insights stemming from the rich literature on Swiss direct democracy to inform this debate. They imply that tagging on direct democratic elements to a multilevel system does not necessarily enhance its democratic quality and the legitimacy of policy decisions. As such, the authors could be criticized for not emphasizing enough that the Brexit referendum happened in the UK political system which has very strong majoritarian elements and a particular relation to the EU. Nevertheless, the article is important because it critically assesses the claim that more direct democracy enhances input legitimacy in multilevel systems and shows that referendums should be combined with other (consensus-oriented) democratic instruments (Papadopoulos and Magnette 2010).

The article by Ege equally adopts a comparative perspective on the administrative structures of the EU with other, even less integrated, international organizations: the Food and Agriculture Organization (FAO) and the Organization for Economic Cooperation and Development (OECD). His article marks a promising contribution to the flourishing literature on International Public Administrations (IPAs) which turns our attention to the understudied and poorly understood aspect of managerial change in IPAs. Ege convincingly argues that the lack of a descriptive tool to compare such change is responsible for the lack of theoretical and empirical knowledge on the causes and consequences thereof, such as administrative effectiveness, efficiency, and other aspects of problem-solving. However, IPAs play an increasingly important autonomous role in multilevel problem-solving above the nation state (see Eckhard and Ege 2016). Management is a crucial driver in these structures. Thus, the time is ripe for the conceptualization and descriptive empirical illustration of management change which Ege contributes to this symposium.

Ege starts out with a comprehensive conceptualization review of the existing literature on management change in IPAs. From this review, we can learn that management change in IPAs can be studied in terms of four dimensions. The first dimension is personnel policies, especially New Public Management (NPM)-style changes in recruitment, remuneration and promotion. A second dimension is finances and particularly the introduction of accrual accounting. Third, IPA management has changed regarding performance measurement and especially the establishment of organization-wide evaluations. A final dimension is organization in terms of changes in specialization. In a second step, Ege applies these concepts to measure management change since the 1990s in the EU Commission, the FAO, and the OECD. This comparison provides insights into how central steering and administrative problem-solving have generally improved in these IPAs over time, while also revealing interesting differences between the three organizations.

The article by Ege contributes to the conceptualization and measurement of problem-solving, particularly that shown in the lower part of Figure 1. Ege's analysis paves the way for more systematic comparative research on the management of IPAs in order to understand how IPAs contribute to the problem-solving capacity of international organizations. The author rightly points out that this is an important precondition for theoretical and conceptual cumulativeness and innovation. While the current contribution remains descriptive and hence does not yet provide 
insight on the drivers and consequences of management change, it empowers Public Administration researchers to engage in such analysis and expand their concepts of management and problem-solving to the international level.

Focusing on the lower part of Figure 1, the article by Tosun et al. adopts a comparative approach. The authors analyse the relationship between the EU and international organizations concerning the generation and the transfer of policy knowledge. The article looks at the delegation of authority within in the EU, notably the delegation of authority to define a policy concept and to transform it into a practical tool, taking environmental policy integration (EPI) as an empirical example. The authors argue convincingly that, on the one hand, EU leadership in the field of environmental policy has resulted in IOs adopting EU models of environmental policy integration without offering relevant input to the EU. On the other hand, after the EU exercised its definitional authority over environmental policy, it delegated it downwards to the member states and the European Environmental Agency (EEA).

Tosun et al. start with the assumptions from rational choice institutionalism, which holds that delegating authority is an attractive option for the EU because it reduces transaction costs, for example costs related to information processing and searching, bargaining and negotiation, as well as monitoring and enforcement, in policy-making. Furthermore, the article holds that the EU delegates policy authority under two conditions: (a) once policy concepts are mature and political uncertainty and oversight costs are not too high, and (b) where the cost of externalizing policy knowledge compensates for costs resulting from political uncertainty and control over policy formulation and implementation. To illustrate their argument, the authors assess policy documents by six IOs and code whether these organizations' policy documents refer to relevant EU legislation or to the EU more broadly. The results show that the EU is a reference point for IOs to use EPI tools and that the EU is open to receive knowledge from IOs in the field of environmental policy integration. To put it in the words of our framework, the EU's political integration, which coincides with policy integration in the field of environmental policy, provides a model for IOs. The 'supervised decentralization' of EU environmental policy permits policy experimentation and allows for the development of clear results. On the other hand, IOs do not offer a lot of concrete input for the EU to foster the development of EPI tools further. Therefore, the EU faces higher transaction costs and produces the relevant policy knowledge itself. Consequently, the delegation of definitional authority occurs sideways to agencies and downwards to member states.

The authors contribute in developing an argument about why jurisdictions delegate authority in a problemsolving process. The article not only applies the approach by Maggetti and Trein to an important policy domain, namely EPI; it also makes a theoretical contribution, in assessing governments' incentives to delegate authority in a multilevel setting based on the rational choice institutionalist literature. This part nicely complements the more functionalist approach by Maggetti and Trein that focuses on problem-solving and problem-generating mechanisms in multilevel systems. Although the empirical part of the article focuses on environmental policy integration and six international organizations, the article demonstrates that it is also important to account for actors' rationality in delegating authority to another level of multilevel systems. These arguments should now be tested on a wider range of policy areas and international organizations.

To conclude, in this introduction we have highlighted the importance of problem-solving in multilevel governance, and distinguished procedural and operational notions of problem-solving. The contributions to this symposium highlight the importance of studying the interplay between integration, functional differentiation and problem-solving in multilevel governance systems. Moreover, they provide fine examples of how a comparative approach not only focused on empirical cases, but also on conceptual and theoretical perspectives, can contribute to this agenda and point to the scope conditions for problem-solving. A renewed analysis of problem-solving in the EU and beyond can give us a better understanding of how such systems can effectively and legitimately tackle governance challenges that are above the nation state. That said, this symposium only provides a starting point for further analysis. On the one hand, the contributions collected here remain largely silent on the role played by different degrees of decentralization and the nature of specific policy problems in the problem-solving process. Moreover, none of the contributions tackles operational notions of problem-solving. Thus, a next step has to be to 'zoom in' on questions of problem tractability and 'wickedness' and how these factors may create specific mechanisms of and/or involve scope conditions for problem-solving both as a process and a result (Thomann et al. 2019). In the longer term, a synthesis of existing frameworks and 
concepts with newly generated insights can contribute to a more comprehensive conceptualization and theorization of problem-solving. Arguably, this would provide a much-needed tool empowering both scholars and practitioners of multilevel governance-especially when increased output legitimacy is a core justification for the latter.

\section{ORCID}

Philipp Trein (1D) https://orcid.org/0000-0001-6217-6675

\section{REFERENCES}

Albert, M., Buzan, B., \& Zürn, M. (2013). Introduction: Differentiation theory and international relations. In M. Albert, B. Buzan, \& M. Zürn (Eds.), Bringing sociology to international relations: World politics as differentiation theory (pp. 1-24). Cambridge: Cambridge University Press.

Ansell, C. K., Trondal, J., \& Øgård, M. (2017). Turbulent governance. In C. K. Ansell, J. Trondal, \& M. Øgård (Eds.), Governance in turbulent times (pp. 1-23). Oxford: Oxford University Press.

Bache, I., Bartle, I., \& Flinders, M. (2014). Multi-level governance. In C. Ansell \& J. Torfing (Eds.), Handbook on theories of governance (pp. 486-498). Cheltenham and Northampton, MA: Edward Elgar.

Bache, l., \& Flinders, M. (Eds.) (2015). Multi-level governance: Essential readings. Cheltenham: Edward Elgar.

Benz, A. (2000). Two types of multi-level governance: Intergovernmental relations in German and EU regional policy. Regional and Federal Studies, 10, 21-44.

Benz, A. (2013). Balancing rigidity and flexibility: Constitutional dynamics in federal systems. West European Politics, 36, 726-749.

Biela, J., Hennl, A., \& Kaiser, A. (2012). Combining federalism and decentralization: Comparative case studies on regional development policies in Switzerland, Austria, Denmark, and Ireland. Comparative Political Studies, 45, 447-476.

Bondarouk, E., \& Mastenbroek, E. (2018). Reconsidering EU compliance: Implementation performance in the field of environmental policy. Environmental Policy Governance, 28, 15-27.

Börzel, T. A., \& Hosli, M. O. (2003). Brussels between Bern and Berlin: Comparative federalism meets the European Union. Governance, 16, 179-202.

Braun, D. (2000). Public policy and federalism. Aldershot: Ashgate.

Braun, D., Ruiz-Palmero, C., \& Schnabel, J. (2017). Consolidation policies in federal states: Conflicts and solutions. London and New York: Routledge.

Cini, M., \& Pérez-Solórzano, N. (2016). Introduction. In M. Cini \& N. Pérez-Solórzano (Eds.), European Union politics (pp. 1-11). Oxford: Oxford University Press.

Cohen, M. D., March, J. G., \& Olsen, J. P. (1972). A garbage can model of organizational choice. Administrative Science Quarterly, 17, 1-25.

De Vries, C. E. (2018). Euroscepticism and the future of European integration. Oxford: Oxford University Press.

Down, I., \& Wilson, C. J. (2008). From 'permissive consensus' to 'constraining dissensus': A polarizing union? Acta Politica, 43, 26-49.

Dunlop, C. A., \& Radaelli, C. M. (2019). Policy instruments, policy learning and politics: Impact assessment in the European Union. Cheltenham: Edward Elgar.

Dunlop, C., Radaelli, C., \& Trein, P. (Eds.) (2018). Learning in public policy: Analysis, modes and outcomes. London: Palgrave Macmillan.

Eckhard, S., \& Ege, J. (2016). International bureaucracies and their influence on policy-making: A review of empirical evidence. Journal of European Public Policy, 23, 960-978.

Ege, J. (2019). Learning from the Commission case: The comparative study of management change in international public administrations. Public Administration, 97, 384-398.

Egeberg, M., \& Trondal, J. (2016). Why strong coordination at one level of government is incompatible with strong coordination across levels (and how to live with it): The case of the European Union. Public Administration, 94, 579-592.

Elgström, O., \& Jönsson, C. (2000). Negotiation in the European Union: Bargaining or problem-solving? Journal of European Public Policy, 7, 684-704.

Elman, C. (2005). Explanatory typologies in qualitative studies of international politics. International Organization, 59, 293-326.

Enderlein, H., Walti, S., \& Zürn, M. (Eds.) (2010). Handbook on multi-level governance. Cheltenham: Edward Elgar.

Falkner, G. (2016). The EU's problem-solving capacity and legitimacy in a crisis context: A virtuous or vicious circle? West European Politics, 39, 953-970. 
Fossum, J. E., \& Jachtenfuchs, M. (2017). Federal challenges and challenges to federalism: Insights from the EU and federal states. Journal of European Public Policy, 24 (Special Issue), 467-632.

Genschel, P., \& Jachtenfuchs, M. (2018). From market integration to core state powers: The eurozone crisis, the refugee crisis and integration theory. JCMS: Journal of Common Market Studies, 56, 178-196.

Haas, E. B. (1958). The uniting of Europe: Political, social, and economic forces, 1950-1957. Stanford, CA: Stanford University Press.

Heclo, H. (1974). Modern social policy in Britain and Sweden: From relief to income maintenance. New Haven, CT: Yale University Press.

Heidbreder, E. G., Stadelmann-Steffen, I., Thomann, E., \& Sager, F. (2019). EU referendums in context: What can we learn from the Swiss case? Public Administration, 97, 370-383.

Hix, S. (2008). What's wrong with the EU and how to fix it. Cambridge: Polity Press.

Hooghe, L., \& Marks, G. (2001). Multi-level governance and European integration. Lanham, MD: Rowman \& Littlefield.

Hooghe, L., \& Marks, G. (2003). Unraveling the central state, but how? Types of multi-level governance. American Political Science Review, 97, 233-243.

Hooghe, L., \& Marks, G. (2009). A postfunctionalist theory of European integration: From permissive consensus to constraining dissensus. British Journal of Political Science, 39, 1-23.

Jordan, A. (1999). The implementation of EU environmental policy: A policy problem without a political solution? Environment and Planning C: Politics and Space, 17, 69-90.

Kamkhaji, J. C., \& Radaelli, C. M. (2017). Crisis, learning and policy change in the European Union. Journal of European Public Policy, 24, 714-734.

Kingdon, J. W. (1995). Agendas, alternatives, and public policies (2nd ed.). New York: HarperCollins.

Kohler-Koch, B., \& Eising, R. (1999). The transformation of governance in the European Union. London and New York: Routledge.

Kohler-Koch, B., \& Rittberger, B. (2006). Review article: The 'governance turn' in EU studies. JCMS: Journal of Common Market Studies, 44 (s1), 27-49.

Leuffen, D., Rittberger, B., \& Schimmelfennig, F. (2012). Differentiated integration: Explaining variation in the European Union. Basingstoke: Palgrave Macmillan.

Lodge, M., \& Wegrich, K. (2014a). Conclusion: Problem-solving capacity and the modern state. In M. Lodge \& K. Wegrich (Eds.), The problem-solving capacity of the modern state: Governance challenges and administrative capacities (pp. 275-294). Oxford and New York: Oxford University Press.

Lodge, M., \& Wegrich, K. (2014b). Introduction: Governance innovation, administrative capacities, and policy instruments. In M. Lodge \& K. Wegrich (Eds.), The problem-solving capacity of the modern state: Governance challenges and administrative capacities (pp. 1-22). Oxford and New York: Oxford University Press.

Lodge, M., \& Wegrich, K. (Eds.) (2014c). The problem-solving capacity of the modern state: Governance challenges and administrative capacities. Oxford and New York: Oxford University Press.

Maggetti, M., \& Moraes, H. C. (2018). The policy-making of investment treaties in Brazil: Policy learning in the context of late adoption. In C. Dunlop, C. Radaelli, \& P. Trein (Eds.), Learning in public policy: Analysis, modes and outcomes (pp. 295-316). London: Palgrave Macmillan.

Maggetti, M., \& Trein, P. (2019). Multilevel governance and problem-solving: Towards a dynamic theory of multilevel policymaking? Public Administration, 97, 355-369.

Marsh, D., \& McConnell, A. (2010). Towards a framework for establishing policy success. Public Administration, 88, 564-583.

Mastenbroek, E., van Voorst, S., \& Meuwese, A. (2016). Closing the regulatory cycle? A meta evaluation of ex-post legislative evaluations by the European Commission. Journal of European Public Policy, 23, 1329-1348.

Mortensen, P. B. (2013). (De-)centralisation and attribution of blame and credit. Local Government Studies, 39, $163-181$.

Papadopoulos, Y. (2010). Accountability and multi-level governance: More accountability, less democracy? West European Politics, 33, 1030-1049.

Papadopoulos, Y., \& Magnette, P. (2010). On the politicisation of the European Union: Lessons from consociational national polities. West European Politics, 33, 711-729.

Papadopoulos, Y., \& Piattoni, S. (2019). The European Semester: Democratic weaknesses as limits to learning. European Policy Analysis. Forthcoming.

Peters, B. G., Capano, G., Howlett, M., Mukherjee, I., Chou, M.-H., \& Ravinet, P. (2018). Designing for policy effectiveness: Defining and understanding a concept. Cambridge: Cambridge University Press.

Piattoni, S. (2010). The theory of multi-level governance: Conceptual, empirical, and normative challenges. Oxford: Oxford University Press.

Pierson, P. (2004). Politics in time: History, institutions, and social analysis. Princeton, NJ: Princeton University Press. 
Rittberger, B., \& Blauberger, M. (2018). Introducing the debate section: 'The EU in crisis: EU studies in crisis?' Journal of European Public Policy, 25, 436-439.

Sager, F. (2005). Metropolitan institutions and policy coordination: The integration of land use and transport policies in Swiss urban areas. Governance, 18, 227-256.

Scharpf, F. W. (1992). Einführung: Zur Theorie von Verhandlungssystemen. In A. Benz, F. W. Scharpf, \& Z. Reinhard (Eds.), Horizontale Politikverflechtung: Zur Theorie von Verhandlungssystemen (pp. 11-27). Frankfurt am Main and New York: Campus Verlag.

Scharpf, F. W. (1997). Introduction: The problem-solving capacity of multi-level governance. Journal of European Public Policy, 4, 520-538.

Scharpf, F. W. (1999). Governing in Europe: Effective and democratic? Oxford: Oxford University Press.

Scharpf, F. W. (2003). Problem-solving effectiveness and democratic accountability in the EU. Max-Planck-Institut für Gesellschaftsforschung Working Paper 3.

Schelkle, W. (2017). The political economy of monetary solidarity: Understanding the euro experiment. Oxford: Oxford University Press.

Schimmelfennig, F., Leuffen, D., \& Rittberger, B. (2015). The European Union as a system of differentiated integration: Interdependence, politicization and differentiation. Journal of European Public Policy, 22, 764-782.

Schmidt, V. A. (2006). Democracy in Europe: The EU and national polities. Oxford: Oxford University Press.

Schmidt, V. A. (2013). Democracy and legitimacy in the European Union revisited: Input, output and 'throughput'. Political Studies, 61, 2-22.

Schout, A., \& Jordan, A. (2005). Coordinated European governance: Self-organizing or centrally steered? Public Administration, 83, 201-220.

Stephenson, P. (2013). Twenty years of multi-level governance: 'Where does it come from? What is it? Where is it going?'. Journal of European Public Policy, 20, 817-837.

Thomann, E. (2015). Customizing Europe: Transposition as bottom-up implementation. Journal of European Public Policy, 22, 1368-1387.

Thomann, E. (2019). Customized implementation of European Union food safety policy: United in diversity? Palgrave Macmillan, International Series on Public Policy. London: Palgrave Macmillan.

Thomann, E., \& Sager, F. (2017). Moving beyond legal compliance: Innovative approaches to EU multilevel implementation. Journal of European Public Policy, 24, 1253-1268.

Thomann, E., Trein, P., \& Maggetti, M. (2019). What's the problem? Multilevel governance and problem-solving. European Policy Analysis. Forthcoming.

Tortola, P. D. (2017). Clarifying multilevel governance. European Journal of Political Research, 56, 234-250.

Tosun, J., De Francesco, F., \& Peters, B. G. (2019). From environmental policy concepts to practicable tools: Knowledge creation and delegation in multilevel systems. Public Administration, 97, 399-412.

Tosun, J., \& Hartung, U. (2018). Decentralising competences in multi-level systems: Insights from the regulation of genetically modified organisms. West European Politics, 41, 803-823.

Tosun, J., \& Lang, A. (2017). Policy integration: Mapping the different concepts. Policy Studies, 38, 553-570.

Tosun, J., Wetzel, A., \& Zapryanova, G. (2014). The EU in crisis: Advancing the debate. Journal of European Integration, 36, 195-211.

Treib, O. (2014). Implementing and complying with EU governance outputs. Living Reviews in European Governance, 9, 1.

Trein, P. (2017). Coevolution of policy sectors: A comparative analysis of healthcare and public health. Public Administration, 95, 744-758.

Trein, P. (2018). Median problem pressure and policy learning: An exploratory analysis of European countries. In C. Dunlop, C. Radaelli, \& P. Trein (Eds.), Learning in public policy: Analysis, modes and outcomes (pp. 243-266). London: Palgrave Macmillan.

Trein, P., Meyer, I., \& Maggetti, M. (2019). The integration and coordination of public policies: A systematic comparative review. Journal of Comparative Policy Analysis: Research and Practice. https://doi.org/10.1080/13876988.2018.1496667

Trondal, J. (2010). An emergent European executive order. Oxford: Oxford University Press.

Vagionaki, T., \& Trein, P. (2019). Learning in political analysis. Political Studies Review. Forthcoming.

Woll, C. (2006). Lobbying in the European Union: From sui generis to a comparative perspective. Journal of European Public Policy, 13, 456-469.

Zhelyazkova, A., Kaya, C., \& Schrama, R. (2016). Decoupling practical and legal compliance: Analysis of member states' implementation of EU policy. European Journal of Political Research, 55, 827-846.

Zürn, M., Walti, S., \& Enderlein, H. (2010). Introduction. In H. Enderlein, S. Walti, \& M. Zürn (Eds.), Handbook on multi-level governance (pp. 1-16). Cheltenham: Edward Elgar. 
How to cite this article: Trein P, Thomann E, Maggetti M. Integration, functional differentiation and problem-solving in multilevel governance. Public Admin. 2019;97:339-354. https://doi.org/10.1111/padm. 12595 